\title{
An Academic Trend in STEM Education from Bibliometric and Co-Citation Method
}

\author{
Yuan-Chung Yu, Shu-Hsuan Chang, and Li-Chih Yu
}

\begin{abstract}
The STEM (Science, Technology, Engineering, and Mathematics) education research still grows continuously in this decade; this study utilized the bibliometric and co-citation method to depict literature characteristics of STEM education, including distribution of journals, publication countries, subject area, most cited references and so on. The analytical data is from querying the database of Social Science Citation Index (SSCI) of ISI Web of knowledge. Data, collected in the database, could be easily analyzed to figure out the popularity of publications and impact of articles through citation indexes. This study provided the distribution of core, relevant, and marginal journal, and describe the academic trend in STEM education.
\end{abstract}

Index Terms-STEM education, bibliometric method, academic trend, co-citation.

\section{INTRODUCTION}

The STEM education was built from the early 1990s, and seen as a key issue for competitiveness or innovation of nations. This paper would like to investigate the characteristics of STEM education literature from 1992 to 2013 through bibliometric and co-citation method. The bibliometric utilizes statistical method of bibliography counting to evaluate the literature growth of a research subject, and the co-citation method points out that relationship between articles. This study retrieved data from Thomson Reuters' Citation database of Social Sciences Citation Index (SSCI) on ISI Web of Knowledge website. The search key word, STEM education, was performed, and 385 bibliographic records were found. This study would like: 1) to find out current situations of STEM education; 2) to identify core journals that contain most part of STEM education literature; 3 ) to list the several important references in STEM education literature.

\section{THE GROWTH OF STEM EDUCATION LITERATURE}

After analyzing the literature collection of STEM education from the ISI database, the publication growth of STEM education from 1992 to 2013 was shown in Fig. 1. The academic trend of STEM education increased rapidly from 2008 .

Manuscript received August 6, 2014; revised October 10, 2014.

Y. C. Yu and S. H. Chang are with the National Changhua University of Education, Changhua city, Taiwan (e-mail: yucc@mail.dali.tc.edu.tw, shc@cc.ncue.edu.tw).

L. C. Yu is with the National Chengchi University, Taipei city, Taiwan (e-mail: 100356502@nccu.edu.tw).

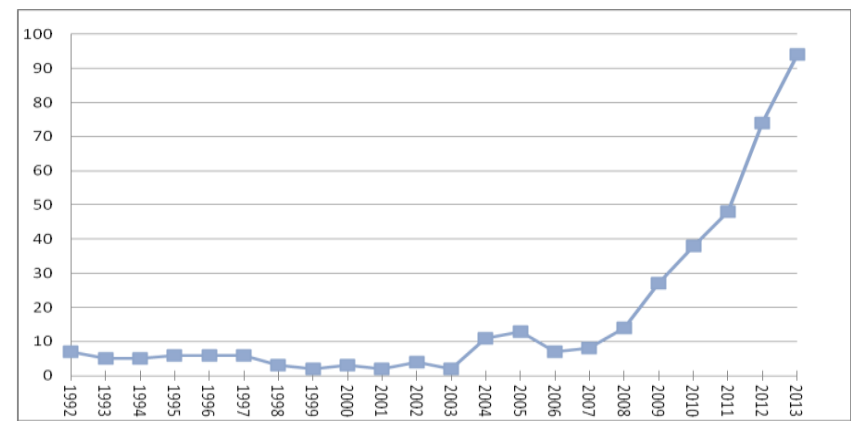

Fig. 1. The academic trend of STEM education literature.

\section{CHARACTERISTICS OF STEM EDUCATION LITERATURE}

\section{A. Country Distribution}

Table I listed country distribution of STEM education literature. USA published around 52\% of STEM education literature. England (12.5\%) and Netherland (11.67\%) contributed the second and third position, and Australia, Spain, Israel, Turkey, Canada, Germany, and Taiwan each of them contributed more than $1.5 \%$ among the total literature.

TABLE I: COUNTRY DISTRIBUTION

\begin{tabular}{ccc}
\hline \hline Country & Record Count & Percent \\
\hline USA & 200 & $51.95 \%$ \\
ENGLAND & 36 & $9.35 \%$ \\
NETHERLANDS & 16 & $4.16 \%$ \\
AUSTRALIA & 16 & $4.16 \%$ \\
SPAIN & 15 & $3.90 \%$ \\
ISRAEL & 14 & $3.64 \%$ \\
TURKEY & 13 & $3.38 \%$ \\
CANADA & 12 & $3.12 \%$ \\
GERMANY & 7 & $1.82 \%$ \\
TAIWAN & 6 & $1.56 \%$ \\
Others & 50 & $12.96 \%$ \\
\hline \hline
\end{tabular}

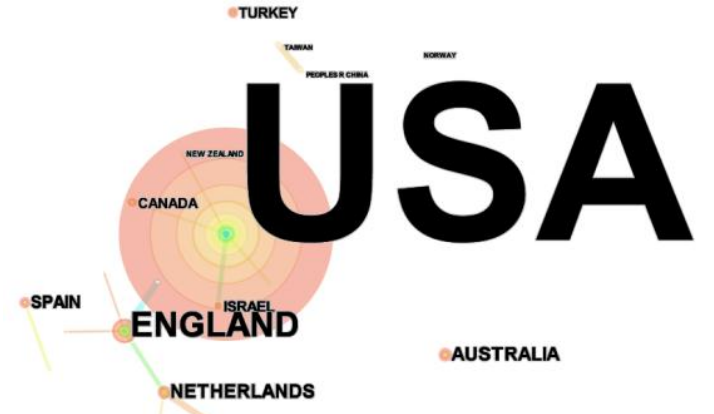

Fig. 2. The visualization of country distribution in STEM education literature.

This study also adopted the visualization tool, CiteSpace 
[1], to plot the relationship of country distribution in Fig. 2. It showed that USA is associated NETHERLANDS, CANADA and ISRAEL.

\section{B. Subject Area}

The top 5 concerned area of STEM education literature included "Education Educational research", "Psychology", "Engineering", "Health care science services" and "Computer science". The major area of STEM education literature was "Education Educational research" for sure. However, the result also indicated that STEM education has been considered as an important issue in "Psychology" as well. Table II lists the most concerned subject area of STEM education literature.

TABLE II: SUBJECT AREA OF STEM EDUCATION LITERATURE

\begin{tabular}{|c|c|c|c|}
\hline Rank & Subject area & Count & Percent \\
\hline 1 & $\begin{array}{c}\text { EDUCATION \& EDUCATIONAL } \\
\text { RESEARCH }\end{array}$ & 122 & $50.83 \%$ \\
\hline 2 & PSYCHOLOGY & 77 & $32.08 \%$ \\
\hline 3 & ENGINEERING & 55 & $22.92 \%$ \\
\hline 4 & HEALTH CARE SCIENCES SERVICES & 28 & $11.67 \%$ \\
\hline 5 & COMPUTER SCIENCE & 20 & $8.33 \%$ \\
\hline 6 & REHABILITATION & 20 & $8.33 \%$ \\
\hline 7 & SOCIAL SCIENCES OTHER TOPICS & 17 & $7.08 \%$ \\
\hline 8 & $\begin{array}{l}\text { PUBLIC ENVIRONMENTAL } \\
\text { OCCUPATIONAL HEALTH }\end{array}$ & 17 & $7.08 \%$ \\
\hline 9 & PHILOSOPHY & 11 & $4.58 \%$ \\
\hline 10 & SPORT SCIENCES & 5 & $2.08 \%$ \\
\hline
\end{tabular}

Fig. 3 also demonstrated the relationship among these subject areas in STEM education, and revealed that all subject areas were not independent, but related.

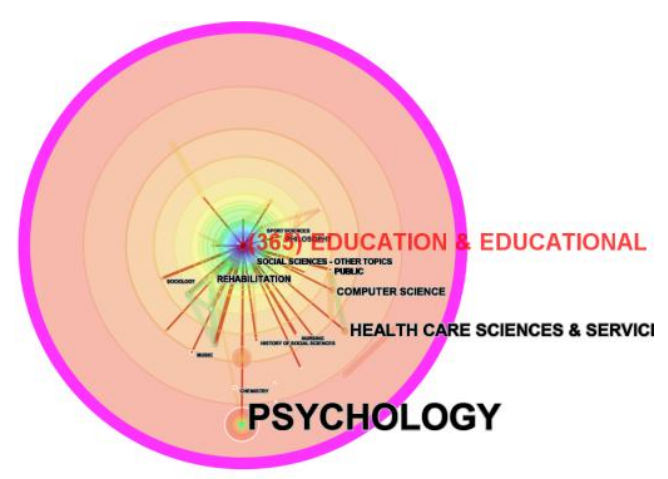

Fig. 3. The visualization of subject area in STEM education literature.

\section{Keywords}

Moreover, this study also conducted the keyword analysis, demonstrating the most popular research issues from published researches. Table III lists the top 15 keywords. Generally, searching keywords for research papers is a convenient way to retrieve data for studying a research domain.
TABLE III: TOP 15 HIGH FREQUENCY KEYWORDS IN STEM EDUCATION LITERATURE

\begin{tabular}{cccc}
\hline \hline Rank & Keyword & Count & Percent \\
\hline 1 & STEM & 16 & $4.16 \%$ \\
2 & science education & 16 & $4.16 \%$ \\
3 & STEM education & 14 & $3.64 \%$ \\
4 & higher education & 11 & $2.86 \%$ \\
5 & education & 10 & $2.60 \%$ \\
6 & Science & 9 & $2.34 \%$ \\
7 & assessment & 8 & $2.08 \%$ \\
8 & curriculum & 7 & $1.82 \%$ \\
9 & diversity & 7 & $1.82 \%$ \\
10 & Qualitative research & 7 & $1.82 \%$ \\
11 & Teacher education & 7 & $1.82 \%$ \\
12 & Technology & 7 & $1.82 \%$ \\
13 & gender & 6 & $1.56 \%$ \\
14 & Recruitment & 6 & $1.56 \%$ \\
15 & Attitudes & 5 & $1.30 \%$ \\
\hline \hline
\end{tabular}

Fig. 4 depicted the relationship among keywords in STEM education, and revealed that the high frequent key were distributed in the centre area, including stem, science education, STEM education, higher education, education, technology, motivation and so on.

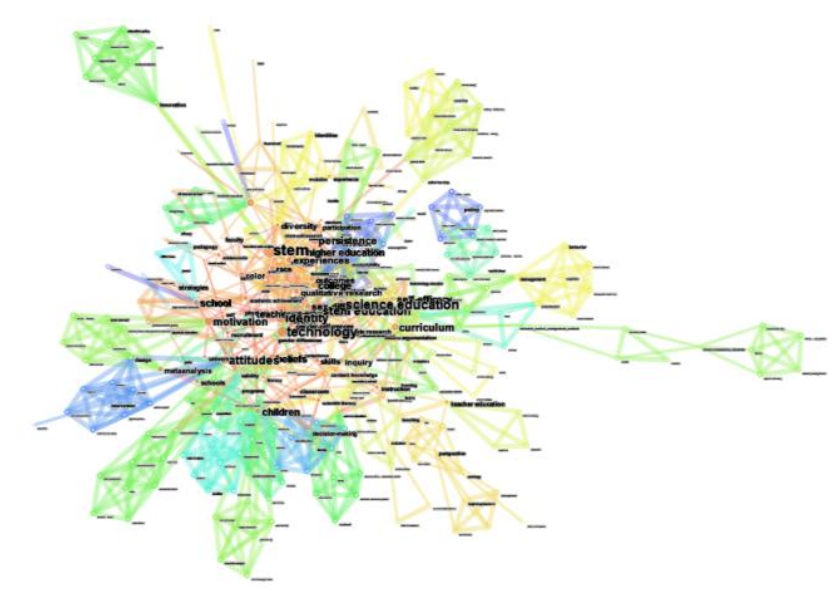

Fig. 4. The visualization of research keywords in STEM education literature.

\section{BRADFORD LAW AND CORE JOURNALS}

Bradford's law [2] pointed out that in a research topic there were a lot of relevant articles collected in a small number of journals, and the rest of articles distributed in the great number of journals. Therefore, Bradford's law proposed the equation, 1: $n: n^{\wedge} 2$, that three groups of journal papers were separated from number of articles in accordance with the proportion. Gillaspy and Huber [3] had utilized it to demonstrate journal literature distribution. This study collected 385 STEM education articles from 169 journals. Table IV listed the amount of articles in each journal. Fig. 5 plotted the cumulative number of articles for each journal for papers of STEM education. The comparisons of three zones (4:24:141) was listed in Table IV, and it was approximately equal to $1: 6: 6^{*} 5.88\left(1: n: n^{\wedge} 2\right)$. The result conformed the Bradford's Law. The core journals and relevant journals (top 7) in STEM education were listed in Table V. 
TABLE IV: THE DISTRIBUTION OF STEM EDUCATION JOURNAL PAPERS

\begin{tabular}{cccccc}
\multicolumn{6}{c}{ TABLE IV: THE DISTRIBUTION OF STEM EDUCATION JouRNAL PAPERS } \\
\hline \hline & $\begin{array}{c}\text { Articles } \\
\text { (a) }\end{array}$ & $\begin{array}{c}\text { Journals } \\
\text { (b) }\end{array}$ & $\begin{array}{c}\text { Accumulate } \\
\text { Amount of articles (a)*(b) } \\
\text { Journals } \\
\text { (c })\end{array}$ & $\begin{array}{c}\text { Accumulated articles } \\
\text { (c ) }\end{array}$ \\
\hline \multirow{2}{*}{ (A) $)$} & 19 & 1 & 19 & 1 & 19 \\
Core & 12 & 2 & 24 & 3 & 43 \\
& 10 & 1 & 10 & 4 & 53 \\
\cline { 2 - 6 } & 9 & 2 & 18 & 6 & 71 \\
& 8 & 4 & 32 & 10 & 103 \\
(B) & 7 & 1 & 7 & 11 & 110 \\
Relevant & 6 & 3 & 18 & 14 & 128 \\
& 5 & 3 & 15 & 17 & 143 \\
& 4 & 11 & 44 & 28 & 187 \\
(C) & 3 & 9 & 27 & 37 & 214 \\
margina & 2 & 39 & 78 & 76 & 292 \\
1 & 1 & 93 & 93 & 169 & 385 \\
\hline \hline
\end{tabular}

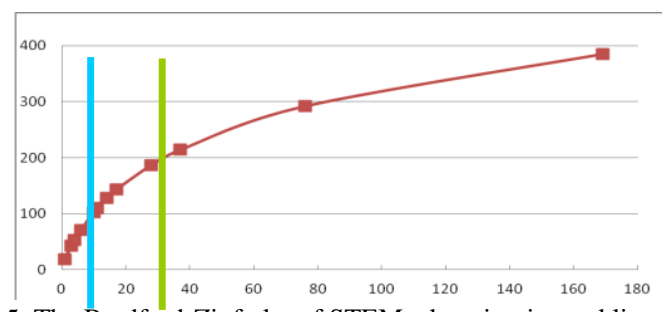

Fig. 5. The Bradford-Zipf plot of STEM education journal literature.

TABLE V: CORE JOURNALS AND TOP 7 RELEVANT JOURNALS TITLE

\begin{tabular}{cccc}
\hline \hline Journal category & Journal title & Count & Percent \\
\hline & INTERNATIONAL JOURNAL OF & 19 & $4.9 \%$ \\
& SCIENCE EDUCATION & \\
& JOURNAL OF SCENCE EDUCATION & 12 & $3.1 \%$ \\
Core journal & AND TECHNOLOGY & 12 & $3.1 \%$ \\
& JOURNAL OF ENGINEERING & 12 & EDUCATION \\
& TEACHERS COLLEGE RECORD & 10 & $2.6 \%$ \\
\cline { 2 - 4 } & RESEARCH IN HIGHER EDUCATION & 9 & $2.3 \%$ \\
& COMPUTERS \& EDUCATION & 9 & $2.3 \%$ \\
Relevant journal & JOUNAL OF RESEARCH IN & 8 & $2.1 \%$ \\
(Top 7) & SCIENCE TEACHING & 8 & $2.1 \%$ \\
& MEDICAL EDUCATION & 8 & $2.1 \%$ \\
& REVISTA DE EDUCACION & 8 & $2.1 \%$ \\
& HIGHER EDUCATION & 7 & $1.8 \%$ \\
\hline \hline & INTERNATIONAL JOURNAL OF & 7 \\
\hline
\end{tabular}

\section{CO-CITATION REFERENCES}

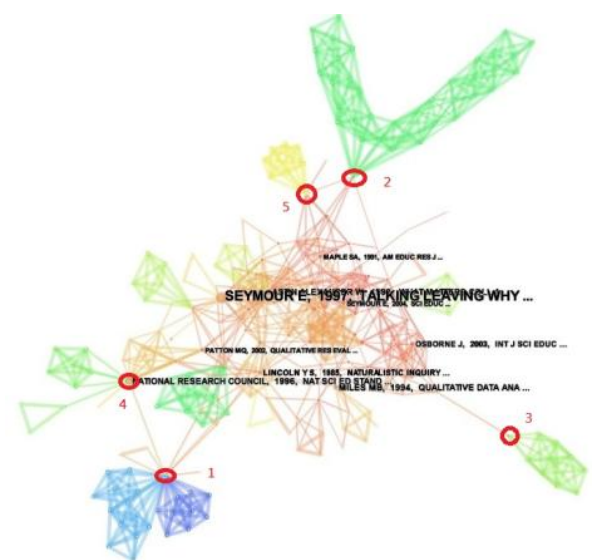

Fig. 6. The visualization of co-citation references in STEM education literature.

After analyzing the co-citation references, the CiteSpace depicted this graph to show the relationship among research references in STEM education (shown in Fig. 6). Table VI listed the top 10 co-cited references in STEM education that might show some insights for those, investigating the STEM education research.

TABLE VI: MOST CO-CITATION REFERENCES IN STEM EDUCATION

\begin{tabular}{|c|c|c|c|}
\hline Authors & & reference title & year \\
\hline $\begin{array}{l}\text { Seymour and } \\
\text { Hewitt [4] }\end{array}$ & \multicolumn{2}{|c|}{$\begin{array}{l}\text { Talking about leaving: Why undergraduates } \\
\text { leave the sciences }\end{array}$} & 1997 \\
\hline $\begin{array}{c}\text { National } \\
\text { Research Council } \\
{[5]}\end{array}$ & \multicolumn{2}{|r|}{ National science education standards } & 1996 \\
\hline $\begin{array}{l}\text { Miles and } \\
\text { Huberman [6] }\end{array}$ & \multicolumn{2}{|r|}{$\begin{array}{c}\text { Qualitative data analysis: An expanded } \\
\text { sourcebook }\end{array}$} & 1994 \\
\hline Astin [7] & \multicolumn{2}{|c|}{$\begin{array}{c}\text { What matters in college?: Four critical years } \\
\text { revisited }\end{array}$} & 1993 \\
\hline $\begin{array}{l}\text { Osborne, Simon, } \\
\text { and Collins [8] }\end{array}$ & \multicolumn{2}{|c|}{$\begin{array}{l}\text { Attitudes towards science: a review of the } \\
\text { literature and its implications }\end{array}$} & 2003 \\
\hline Lincoln [9] & \multicolumn{2}{|r|}{ Naturalistic inquiry (Vol. 75) } & 1985 \\
\hline $\begin{array}{l}\text { Seymour, Hunter, } \\
\text { Laursen, and } \\
\text { DeAntoni [10] }\end{array}$ & \multicolumn{2}{|c|}{$\begin{array}{c}\text { Establishing the benefits of research } \\
\text { experiences for undergraduates in the } \\
\text { sciences: First findings from a three- year } \\
\text { study }\end{array}$} & 2004 \\
\hline Patton [11] & \multirow{2}{*}{\multicolumn{2}{|c|}{$\begin{array}{l}\text { Designing qualitative studies } \\
\text { Influences on the choice of math/science } \\
\text { major by gender and ethnicity. }\end{array}$}} & 2002 \\
\hline $\begin{array}{l}\text { Maple and Stage } \\
{[12]}\end{array}$ & & & 1991 \\
\hline Schön [13] & \multicolumn{2}{|c|}{$\begin{array}{l}\text { Educating the reflective practitioner: Toward } \\
\text { a new design for teaching and learning in the } \\
\text { professions }\end{array}$} & 1987 \\
\hline \multicolumn{4}{|c|}{ TABLE VII: MOST CO-CITATION REFERENCES IN STEM EDUCATION } \\
\hline Item & & reference title & year \\
\hline \multicolumn{2}{|c|}{$\begin{array}{l}\text { Brown, } \\
\text { Collins and } \\
\text { Duguid [14] }\end{array}$} & $\begin{array}{l}\text { Situated cognition and the culture } \\
\text { of learning }\end{array}$ & 1989 \\
\hline $\begin{array}{r}\text { Band } \\
{[15}\end{array}$ & $\begin{array}{c}\text { Bandura } \\
\text { [15] }\end{array}$ & $\begin{array}{l}\text { Social foundations of thought and } \\
\text { action }\end{array}$ & 1986 \\
\hline Schö & Schön [13] & $\begin{array}{l}\text { Educating the reflective } \\
\text { practitioner: Toward a new design } \\
\text { for teaching and learning in the } \\
\text { professions }\end{array}$ & 1987 \\
\hline $\begin{array}{l}\text { Nati } \\
\text { Res } \\
\text { Coun }\end{array}$ & $\begin{array}{l}\text { National } \\
\text { Research } \\
\text { Council [5] }\end{array}$ & $\begin{array}{l}\text { National science education } \\
\text { standards }\end{array}$ & 1996 \\
\hline $\begin{array}{r}\text { Ade } \\
{[1}\end{array}$ & $\begin{array}{l}\text { Adelman } \\
{[16]}\end{array}$ & $\begin{array}{l}\text { Women and Men of the Engineering } \\
\text { Path: A Model for Analyses of } \\
\text { Undergraduate Careers }\end{array}$ & 1998 \\
\hline
\end{tabular}


In above mentioned core journals, researchers could select several key papers to inquiry knowledge in STEM education. However, they may be interested in knowing overall picture of the specific research domain. From the co-citation perspective, this study provided 5 references to show the important nodes that connected the different disciplines and the researchers may be interested in STEM education (Table VII).

\section{CONCLUSION}

This paper investigated the academic trend in STEM education literature by means of analyzing the SSCI database, and depicted some characteristics of STEM education literature from bibliometric and co-citation method. This paper proposed several findings as followings: 1) the research in STEM education is increasing rapidly in this decade. 2) 4 core journals were identified by the Bradford law, and 53 research papers $(13.77 \%)$ of STEM education were collected in the top 4 journals and the rest $86 \%$ was widely indexed in other 165 journals. 3) This study listed the key references, including the most co-citation references and the co-citation references connecting different disciplines to show the overall picture in STEM education.

\section{REFERENCES}

[1] C. Chen, "CiteSpace II: Detecting and visualizing emerging trends and transient patterns in scientific literature," J. Am. Soc. Inform. Sci. Tech., vol. 57, no. 3, pp. 359-377, 2006.

[2] S. C. Bradford, "Sources of information on specific subjects," $J$. Inform. Sci., vol. 10, no. 4, pp. 173-180, 1985.

[3] M. L. Gillaspy and J. T. Huber, "The literature of women and the acquired immunodeficiency syndrome (AIDS): Implications for collection development and information retrieval," Med. Ref. Ser. Quart, vol. 15, no. 4, pp. 21-39, 1996.

[4] E. Seymour and N. M Hewitt, Talking about Leaving: Why Undergraduates Leave the Sciences, vol. 12, Boulder, CO: Westview Press, 1997.

[5] National Research Council (Ed.), National Science Education Standards, National Academy Press, 1996.

[6] M. B. Miles and A. M. Huberman, Qualitative Data Analysis: An Expanded Sourcebook, Beverly Hills: Sage Publications, 1994.

[7] A. W. Astin, What Matters in College?: Four Critical Years Revisited, San Francisco: Jossey-Bass, 1993.

[8] J. Osborne, S. Simon, and S. Collins, "Attitudes towards science: a review of the literature and its implications," Int. J. Sci. Edu., vol. 25, no. 9, pp. 1049-1079, 2003.
[9] Y. S. Lincoln, Naturalistic Inquiry, vol. 75, Beverly Hills: Sage Publications, 1985.

[10] E. Seymour, A. B. Hunter, S. L. Laursen, and T. DeAntoni, "Establishing the benefits of research experiences for undergraduates in the sciences: First findings from a three year study," Sci. Edu., vol. 88, no. 4, pp. 493-534, 2004.

[11] M. Q. Patton, "Designing qualitative studies," Qual. Res. Eval. Method, vol. 3, pp. 230-246, 2002.

[12] S. A. Maple and F. K., "Stage, influences on the choice of math/science major by gender and ethnicity," Am. Educ. Res. J., vol. 28, no. 1, pp. 37-60, 1991

[13] D. A. Schön, Educating the Reflective Practitioner: Toward a New Design for Teaching and Learning in the Professions, San Francisco, CA: Jossey-Bass, 1987.

[14] J. S. Brown, A. Collins, and P. Duguid, "Situated cognition and the culture of learning," Educational Researcher," vol. 18, no. 1, pp. $32-42,1989$

[15] A. Bandura, Social Foundations of Thought and Action, Englewood Cliffs, NJ: Prentice Hall, 1986

[16] C. Adelman, Women and Men of the Engineering Path: A Model for Analyses of Undergraduate Careers, US Government Printing Office, Superintendent of Documents, Mail Stop: SSOP, Washington DC 20402-9328, 1998

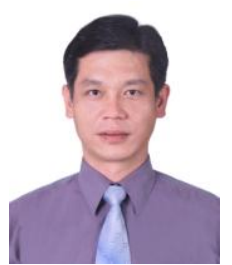

Yuan-Chung Yu is a Ph.D student at the Department of Industrial Education and Technology, National Changhua University of Education (NCUE), Taiwan. $\mathrm{He}$ received the master degree in the Department of Mathematics from National Kaohsiung Normal University, Taiwan. His research interests include decision-making science, technological education, and educational administration and evaluation.

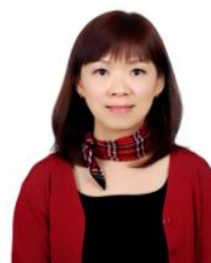

Shu-Hsuan Chang is currently a professor of the Department of Industrial Education and Technology as well as the director of e-Learning Center, National Changhua University of Education (NCUE), Taiwan She received the B.S. and M.S. degrees in industrial engineering from National Chiao-Tung University, Taiwan, and the Ph.D. degree in Department of Industrial Education and Technology from NCUE, Taiwan. Her research interests include decision-making science, technology management, innovation management, engineering \& technological education, and photonics.

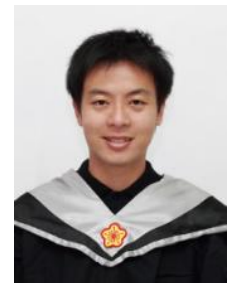

Li-Chih Yu is a Ph.D student at the Department of Management Information System, National Chengchi University, Taiwan. He received his master degree from the Department of Management Information System, National Changhua University of Education, Taiwan. His research interests include e-learning, business intelligence, and entrepreneurship education. 